\title{
Attitude and behaviors of mothers regarding fever in children; a Duzce University Faculty of Medicine study
}

\author{
Annelerin ateşli çocuklarda tutum ve davranışları; Düzce Üniversitesi Tıp Fakültesi örneği \\ (D) Onder Kilicaslan ${ }^{\mathrm{a}}$, Cemil Isik Sonmez, (D) Damla Dincer ${ }^{\mathrm{b}}$ (D) Yunus Sengun ${ }^{\mathrm{b}}$, (Damazan Cahit \\ Temizkan ${ }^{\mathrm{a}}$ (Decep Eroz', (Denan Kocabay ${ }^{\mathrm{a}}$ \\ ${ }^{a}$ Duzce University, School of Medicine, Department of Pediatrics, Duzce, Turkey \\ b Duzce University, School of Medicine, Department of Family Medicine, Duzce, Turkey \\ ${ }^{\mathrm{c}}$ Duzce University, School of Medicine, Department of Medical Genetics, Duzce, Turkey
}

\begin{abstract}
Introduction: In mothers with fever complaint who applied to Duzce University Faculty of Medicine Research and Practice Hostipal, defining attitude and behaviours and general knowledge levels about fever are aimed in this study.

Methods: 230 patients who were admitted to pediatric emergency service and general pediatric outpatient clinics from February to June 2017 were included in the study. Questionnaires with 26 questions were evaluated in this study. Descriptive features, chi-square test and one-way ANOVA followed by Bonferroni's post-hoc comparisons tests were performed in all statistical analyzes.

Results: It was learned that $79.1 \%$ of the mothers were placing the thermometers under the armpit during measurement. Most of the mothers picked the normal body temperature as $35.5-36.4^{\circ} \mathrm{C}(57.8 \%) .74 .8 \%$ of the mothers considered fever as a disease and $98.7 \%$ of the mothers thought that fever was harmful. Most of the mothers were considering the advices of doctors on reducing fever of children (48.7\%). The most common intervention to reduce fever was to shower with warm water $(73.5 \%)$. The most preferred antipyretic was paracetamol $(76.1 \%)$. As the education levels increased, rates of showering with warm water and taking out the children's clothes were increasing significantly $(\mathrm{p}=0.027, \mathrm{p}=0.025$, respectively).

Conclusion: In this study, it was seen that the mother's general knowledge about fever was inadequate and there were occasionally wrong attitudes and behaviors in order to reduce fever. We think that detailed information about fever given to the families by physicians will prevent unnecessary applications in this area.
\end{abstract}

Keywords: Mother, Fever, Child, Behaviour, Attitude

\section{$\ddot{O ̈ Z}$}

Giriş: Bu çalışma ile Düzce Üniversitesi Tıp Fakültesi Araştırma ve Uygulama Hastanesi'ne ateş şikâyeti ile başvuran annelerin ateş hakkındaki genel bilgi düzeylerinin ve ateşli çocuklara karşı tutum ve davranışlarının belirlenmesi amaçlanmıştır.

Yöntem: Şubat Haziran 2017 tarihleri arasında çocuk acil servis ve genel çocuk polikliniklerine başvuran 230 hasta çalışmaya alındı. Çalışmada 26 sorudan oluşan anket değerlendirildi. İstatistiksel analizlerde tanımlayıcı özellikler ki-kare testi ve Bonferonni düzeltmeli one way ANOVA kullanıldı. Bulgular: Annelerin \%79,1'inin ateşi koltuk altından ölçtüğü öğrenildi. Annelerin büyük kısmı normal vücut sıcaklığın $135,5-36,4^{\circ} \mathrm{C}$ olarak işaretledi $(\% 57,8)$. Annelerin \%74,8'i ateşin bir hastalık olduğunu ve \%98,7'si de yüksek ateşin zararlı olduğunu düşünüyordu. Annelerin ateş düşürmek için en sık öneriyi doktorlardan aldıkları öğrenildi $(\% 48,7)$. Ateşi düşürmek için yapılan en sık müdahale 1lık su ile duş olarak tespit edildi $(\% 73,5)$. En çok tercih edilen ateş düşürücü \%76,1 parasetamol idi. Eğitim düzeyi arttıkça 1lık su ile duş ve çocuğun üzerindekilerini çıkarma cevabını verme oranı anlamlı olarak artmaktaydı (sırasıla $\mathrm{p}=0,027 ; \mathrm{p}=0,025$ ).

Sonuç: Bu çalışmada annelerin ateş hakkındaki genel bilgi düzeylerinin yetersiz olduğu ve ateşi düşürmek adına zaman zaman yanlış tutum ve davranışlarının olduğu görüldü. Ailelerin ateş konusunda hekimler tarafından detaylı bilgilendirilmeleri ile bu konudaki gereksiz uygulamaların önüne geçileceğini düşünmekteyiz.

Anahtar kelimeler: Anne, Ateș, Çocuk, Davranıș, Tutum

Submission: Nov 16, 2017

Acceptance: Mar 02, 2018

E-Mail: drcemilsonmez@gmail.com

Correspondence: Cemil Isik Sonmez, MD

Duzce University, School of Medicine, Department of Family Medicine, Duzce, Turkey, 81000

www.fppc.com.tr 


\section{Giriș}

Ateş, vücut sıcaklığının normal olmayan bir nedene verilen yanıt olarak günlük ortalamanın üzerine çıkması şeklinde tanımlanmaktadır. Pek çok bilimsel kaynakta $38^{\circ} \mathrm{C}$ ve üzeri ateş olarak tanımlanır [1]. Vücut sıcaklığındaki bu patolojik artış altta yatan bir durumun semptomu olarak düşünülmelidir [2]. Ateş; hekimler başta olmak üzere sağlık çalışanları için doğal bir savunma reaksiyonu olarak kabul edilse de aileler tarafından endişe ile karşılanan bir durumdur ve acil servislere başvuruların en sık nedenini oluşturmaktadır [3].

Ateş ile ilgili her kültürde farklı halk inanışları ve yaklaşımları vardır. Çoğu zaman aileler tarafından ciddi bir hastalık olarak kabul edilerek gereksiz panik ve korku ile acele ve yanlış müdahalelerde bulunulmaktadır. Genellikle çocuğun kıyafetlerini çıkarma, 1lık su ile duş ve ateş düşürücü ilaç kullanımı gibi doğru yöntemler kullanılıyor olsa da; ateş düşürücü dozunu göz kararı belirleme, alkol ve sirkeli su pansumanı gibi yanlış periferik soğutma yöntemlerine başvurulduğu da görülmektedir. Bu çalışma ile Düzce Üniversitesi Tıp Fakültesi Araştırma ve Uygulama Hastanesi'ne ateş şikâyeti ile başvuran annelerin ateş hakkındaki genel bilgi düzeylerinin ve ateşli çocuklara karşı tutum ve davranışlarının değerlendirilerek belirlenmesi amaçlanmıştır.

\section{Yöntem}

Şubat 2017-Haziran 2017 tarihleri arasında Düzce Üniversitesi Tıp Fakültesi Araştırma ve Uygulama Hastanesi çocuk acil servis ve genel çocuk polikliniklerine ateş şikâyeti ile başvuran ve/veya ateş etyolojisi araştırılmak üzere çocuk servisinde takip edilen ve anket doldurmayı kabul eden 230 anne çalışmaya alındı. Çalışma için Düzce Üniversitesi Tıp Fakültesi Etik Kurulundan onay alındı (2017/25).

Annelere yüz yüze görüşme metodu ile çalışmanın amacı anlatılıp takiben sosyo-demografik özeliklerini ve ateş hakkında tutum ve davranışlarını belirleyen toplam 26 soru soruldu.

Çocuk acil servisine, genel pediatri polikliniğine, pediatri servisine başka sebeplerle başvuran hastalar (travma, ilaç içme, göğüs ağrısı, kabızlık vb.), kontrol için başvuran hastalar, anne dışında baba veya herhangi bir yakını tarafından doldurulan anketler ve eksik dolduran anketler çalışma dışı birakild1.

\section{İstatistiksel Analiz}

Araştırmadan elde edilen veriler SPSS 21,0 (SPSS, Inc, Chicago, Illinois) istatistik programı kullanılarak değerlendirildi. İstatistiksel analizlerde tanımlayıcı özellikler ki-kare testi ve Bonferonni düzeltmeli one way ANOVA kullanıldı. Sayısal değerler sürekli ve kesikli numerik değerler biçiminde ve yüzdelerle belirtildi. Sonuçlar \%95 güven aralığında, $\mathrm{p}<0,05$ anlamlılık düzeyinde değerlendirildi.

\section{Bulgular}

Çalışmada tamamı anneler tarafından doldurulan toplam 230 anket değerlendirildi. Çalışmaya katılan annelerin yaş ortalaması $29,97 \pm 6,65$ yıl (en büyük: 46 yaş, en küçük 18 yaş), çocukların ise 24,82 $\pm 24,43$ ay (en küçük: 1 ay, en büyük 120 ay) idi. Yüz otuz iki çocuk erkek (\%57,4), 98 çocuk ise kız $(\% 42,6)$ idi. Aileler çoğunlukla anne baba ve çocuklardan oluşan çekirdek aile şeklindeydi $(\% 74,3)$ ve ortalama çocuk sayısı $2,1 \pm 1,07$ idi. Çalışmaya katılan annelerin sadece 1 tanesi okuma yazma bilmiyordu (Tablo 1).

Annelerin büyük kısmı normal vücut sıcaklığını $35,5-36,4^{\circ} \mathrm{C}$ olarak işaretledi $(\% 57,8)$. Yüksek ateş kaç derece ve üstüdür şeklindeki soru ise $\% 53,0$ oranında $38^{\circ} \mathrm{C}$ ve üstü olarak cevaplandı. Annelerden ateş durumunda hissettikleri endişeyi 0'dan 10'a kadar puanlamaları istendi. En yüksek puan olarak 10 işaretlenmişti $(\% 26,9)$ ve 5 puan üstü cevaplanma oranı \%63,9 idi. Annelerin \%97,8'i ateş ölçer kullanırken bunların \%79,1'inin ateşi koltuk altından ölçtüğü öğrenildi. Annelerin \%74,8'i ateşin bir hastalık olduğunu ve \%98,7'si de yüksek ateşin zararlı olduğunu düşünüyordu. En yüksek oranda cevaplanan zarar \%93,4 ile ateşli havaleydi (Tablo 2). Çocukların sadece 13 tanesinde $(\% 5,7)$ febril konvulsiyon hikâyesi mevcuttu.

Annelerin ateş düşürmek için en sık öneriyi doktorlardan aldıkları öğrenildi (\%48,7). Çocukların 168 tanesinin (\%73) sürekli bir doktor tarafindan takipte olduğu öğrenildi ve doktorların 112 tanesi $(\% 66,7)$ çocuk doktoru, 56 tanesi $(\% 33,3)$ aile hekimiydi. Ateşi düşürmek için yapılan en sık müdahale 11 k su ile duş olurken $(\% 73,5)$, ikinci sıklıkta ateş düşürücü ilaç vermek bulunmaktaydı $(\% 69,1)$. Ateşi evde düşüremeyen anneler çocukları doktora götürmekteydi $(\% 89,1)$ ve çok az kısmının hiçbir şey yapmadan beklemeyi tercih ettiği öğrenildi (\%1,3). En çok tercih edilen ateş düşürücü $\% 76,1$ parastemol idi ve genellikle reçeteli temin ediliyordu (\%86,5). Anneler ateş düşürücü dozunu en sık doktor önerisine göre ayarlarken (\%48,7), genelde 4 saat ara ile $(\% 60,4)$ ve $38^{\circ} \mathrm{C}$ ve üstünde $(\% 67,8)$ ilaç kullandıkları öğrenildi (Tablo 3$)$. 
Tablo 1. Aile tipi, çocuk sayısı ve anne eğitim düzeyleri, $N, \%$

\begin{tabular}{llll}
\hline & & $\mathbf{N}$ & $\%$ \\
\hline \multirow{2}{*}{ Aile tipi } & Çekirdek Aile & 171 & 74,3 \\
& Geniş Aile & 59 & 25,7 \\
Çocuk sayısı & 1 & 76 & 33 \\
& 2 & 86 & 37,4 \\
& 3 & 47 & 20,5 \\
& 4 & 13 & 5,7 \\
Anne eğitimi & 5 & 7 & 3 \\
& 6 & 0 & 0 \\
& 7 & 1 & 0,4 \\
& Okuryazar Değil & 1 & 0,4 \\
& Okuryazar & 4 & 1,7 \\
& İlköğretim & 119 & 51,7 \\
\hline
\end{tabular}

Tablo 2. Annelerin ateş ile ilgili genel bilgi düzeyleri

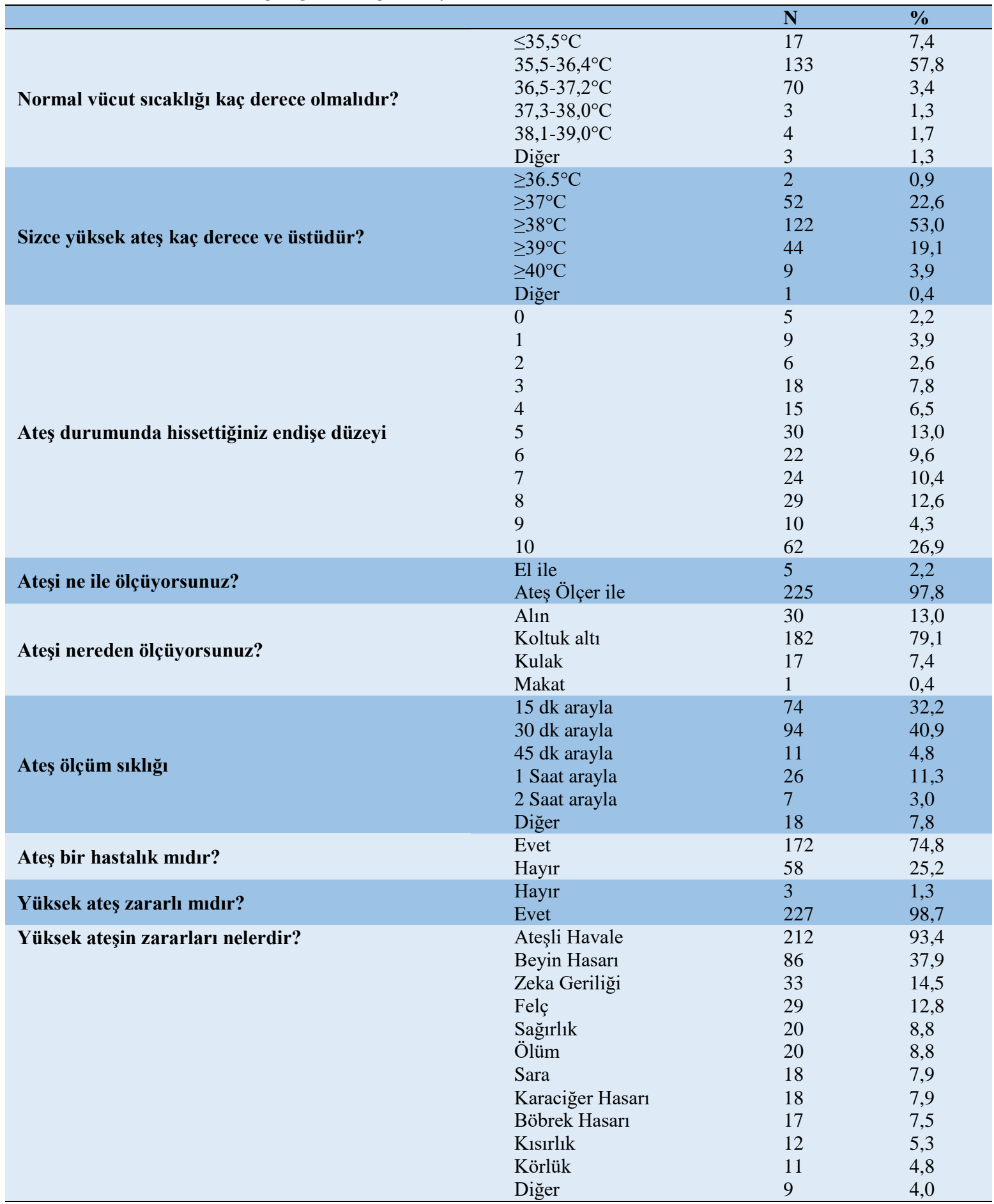


Tablo 3. Annelerin ateş düşürülmesi ile ilgili yaklaşımları ve genel bilgi düzeyleri

\begin{tabular}{|c|c|c|c|}
\hline & & $\mathbf{N}$ & $\%$ \\
\hline \multirow{8}{*}{$\begin{array}{l}\text { Ateş düşürmek için kimin önerisini } \\
\text { alıyorsunuz }\end{array}$} & Doktor & 112 & 48,7 \\
\hline & Kendi bilgilerim & 74 & 32,2 \\
\hline & Büyükanne & 12 & 5,2 \\
\hline & Internet & 11 & 4,8 \\
\hline & Hemşire & 11 & 4,8 \\
\hline & Komşu & 4 & 1,7 \\
\hline & Eczacı & 3 & 1,3 \\
\hline & Diğger & 3 & 1,3 \\
\hline \multirow{13}{*}{$\begin{array}{l}\text { Ateş düşürmek için ne/neler } \\
\text { yaparsınız }\end{array}$} & Ilık Su İle Duş & 169 & 73,5 \\
\hline & Ateş Düşürücü İlaç Vermek & 159 & 69,1 \\
\hline & Üzerini Çıkarma & 123 & 53,5 \\
\hline & Ilık Tampon İle Müdahale & 90 & 39,1 \\
\hline & Sirkeli Su İle Müdahale & 35 & 15,2 \\
\hline & Direk Doktora Götürmek & 34 & 14,8 \\
\hline & Soğuk Su İle Duş & 14 & 6,1 \\
\hline & Kolonya Sürmek & 2 & 0,9 \\
\hline & Diğer Öneriler & 2 & 0,9 \\
\hline & S1k1 Giydirerek Terletmek & 1 & 0,4 \\
\hline & Antibiyotik Vermek & 1 & 0,4 \\
\hline & İspirto Sürmek & 0 & 0 \\
\hline & Hiçbir Şey Yapmamak & 0 & 0 \\
\hline \multirow{4}{*}{$\begin{array}{l}\text { Evde ateşi düşüremezseniz ne/neler } \\
\text { yaparsınız }\end{array}$} & Direk Doktora Götürmek & 205 & 89,1 \\
\hline & İlk Uygulamaları Tekrarlamak & 16 & 7,0 \\
\hline & Ateş Düşürücü Dozunu Artırmak & 6 & 2,6 \\
\hline & Beklemek & 3 & 1,3 \\
\hline \multirow{8}{*}{$\begin{array}{l}\text { Ateş düşürücü dozunu neye göre } \\
\text { karar veriyorsunuz }\end{array}$} & Doktor Önerisi & 142 & 61,7 \\
\hline & Kilo & 69 & 30,0 \\
\hline & Yaş & 39 & 17,0 \\
\hline & Göz Kararı & 15 & 6,5 \\
\hline & Eczacı Önerisi & 13 & 5,7 \\
\hline & Ateş Derecesi & 12 & 5,2 \\
\hline & Boy & 2 & 0,9 \\
\hline & Diğer & 1 & 0,4 \\
\hline \multirow{5}{*}{$\begin{array}{l}\text { Kaç saat ara ile ateş düşürücü } \\
\text { veriyorsunuz }\end{array}$} & 2 & 17 & 7,4 \\
\hline & 4 & 139 & 60,4 \\
\hline & 6 & 42 & 18,3 \\
\hline & 8 & 22 & 9,6 \\
\hline & Diğer & 10 & 4,3 \\
\hline \multirow{5}{*}{$\begin{array}{l}\text { Kaç derecede ateş düşürücü } \\
\text { veriyorsunuz }\end{array}$} & Ölçmeden & 6 & 2,6 \\
\hline & $\geq 37^{\circ} \mathrm{C}$ & 48 & 20,9 \\
\hline & $\geq 38^{\circ} \mathrm{C}$ & 156 & 67,8 \\
\hline & $\geq 39^{\circ} \mathrm{C}$ & 19 & 8,3 \\
\hline & Diğer & 1 & 0,4 \\
\hline \multirow{2}{*}{$\begin{array}{l}\text { Ateş düşürücüyü nasıl temin } \\
\text { ediyorsunuz }\end{array}$} & Reçeteli & 199 & 86,5 \\
\hline & Reçetesiz & 31 & 13,5 \\
\hline \multirow{4}{*}{$\begin{array}{l}\text { Ateş düşürücü ilaç olarak en çok neyi } \\
\text { kullanıyorsunuz }\end{array}$} & Parastemol & 175 & 76,1 \\
\hline & İbuprofen & 132 & 57,4 \\
\hline & Parastemol+Fenilefrin & 7 & 3,0 \\
\hline & İbuprofen+Pseudoefedrin & 7 & 3,0 \\
\hline
\end{tabular}

Annelerin ateş düşürmek için ne/neler yaparsınız sorusuna verdikleri cevaplar eğitim düzeyleri ile karşılaştırıldı. Eğitim düzeyi arttıkça 1lık su ile duş ve çocuğun üzerindekilerini çıkarma cevabını verme oranı anlamlı olarak artmaktaydı $(p=0,027-p=0,025)$. Diğer cevaplarda ise eğitim düzeyler arasında anlamlı fark saptanmadı ( $>0,05)$ (Tablo 4). 
Tablo 4: Ateş düşürmek için ne/neler yaparsınız sorusunun, annelerin eğitim düzeyleri ile karşılaştırılması

\begin{tabular}{|c|c|c|c|c|c|c|c|c|c|}
\hline \multirow{2}{*}{\multicolumn{2}{|c|}{ Ateş düşürmek için ne/neler yaparsınız }} & \multirow{3}{*}{$\begin{array}{l}\text { OYD } \\
0\end{array}$} & \multirow{3}{*}{$\begin{array}{l}\text { OY } \\
2\end{array}$} & \multirow{3}{*}{$\begin{array}{l}\text { İÖ } \\
83\end{array}$} & \multirow{3}{*}{$\begin{array}{l}\mathbf{L} \\
63\end{array}$} & \multirow{3}{*}{$\begin{array}{l}\text { YÖ } \\
21\end{array}$} & \multicolumn{2}{|c|}{$\mathbf{T}$} & \multirow{2}{*}{$\mathbf{p}$} \\
\hline & & & & & & & (n) & $(\%)$ & \\
\hline \multirow{2}{*}{ Ilık Su İle Duş } & Evet & & & & & & 169 & 73,5 & \multirow{2}{*}{$\mathbf{0 , 0 2 7}$} \\
\hline & Hayır & 1 & 2 & 36 & 11 & 11 & 61 & 26,5 & \\
\hline \multirow{2}{*}{ Ateş düşürücü ilaç vermek } & Evet & 1 & 2 & 81 & 53 & 22 & 159 & 69,1 & \multirow{2}{*}{0,842} \\
\hline & Hayır & 0 & 2 & 38 & 21 & 10 & 71 & 30,9 & \\
\hline \multirow{2}{*}{ Üzerini çıkarma } & Evet & 0 & 1 & 59 & 38 & 25 & 123 & 53,5 & \multirow{2}{*}{$\mathbf{0 , 0 2 5}$} \\
\hline & Hayır & 1 & 3 & 60 & 36 & 7 & 107 & 46,5 & \\
\hline \multirow{2}{*}{ Ilık tampon ile müdahale } & Evet & 0 & 1 & 42 & 32 & 15 & 90 & 39,1 & \multirow{2}{*}{0,550} \\
\hline & Hayır & 1 & 3 & 77 & 42 & 17 & 140 & 60,9 & \\
\hline \multirow{2}{*}{ Sirkeli su ile müdahale } & Evet & 1 & 1 & 19 & 12 & 2 & 35 & 15,2 & \multirow{2}{*}{0,093} \\
\hline & Hayır & 0 & 3 & 100 & 62 & 30 & 195 & 84,8 & \\
\hline \multirow{2}{*}{ Direk doktora götürmek } & Evet & 0 & 2 & 16 & 13 & 3 & 34 & 14,8 & \multirow{2}{*}{0,242} \\
\hline & Hayır & 1 & 2 & 103 & 61 & 29 & 196 & 85,2 & \\
\hline \multirow{2}{*}{ Soğuk su ile duş } & Evet & 0 & 1 & 5 & 6 & 2 & 14 & 6,1 & \multirow{2}{*}{0,428} \\
\hline & Hayır & 1 & 3 & 114 & 68 & 30 & 216 & 93,9 & \\
\hline \multirow{2}{*}{ Kolonya sürmek } & Evet & 0 & 0 & 1 & 1 & 0 & 2 & 0,9 & \multirow{2}{*}{0,971} \\
\hline & Hayır & 1 & 4 & 118 & 73 & 32 & 228 & 99,1 & \\
\hline \multirow{2}{*}{ Diğer öneriler } & Evet & 0 & 0 & 1 & 0 & 1 & 2 & 0,9 & \multirow{2}{*}{0,630} \\
\hline & Hayır & 1 & 4 & 118 & 74 & 31 & 228 & 99,1 & \\
\hline \multirow{2}{*}{ Sıkı giydirerek terletmek } & Evet & 0 & 0 & 1 & 0 & 0 & 1 & 0,4 & \multirow{2}{*}{0,919} \\
\hline & Hayır & 1 & 4 & 118 & 74 & 32 & 229 & 99,6 & \\
\hline \multirow{2}{*}{ Antibiyotik vermek } & Evet & 0 & 0 & 0 & 1 & 0 & 1 & 0,4 & \multirow{2}{*}{0,714} \\
\hline & Hayır & 1 & 4 & 119 & 73 & 32 & 229 & 99,6 & \\
\hline İsnirte sürmek & Evet & 0 & 0 & 0 & 0 & 0 & 0 & 0 & $<0,00$ \\
\hline Ispirto surmek & Hayır & 1 & 4 & 119 & 74 & 32 & 230 & 100 & 1 \\
\hline Hichi & Evet & 0 & 0 & 0 & 0 & 0 & 0 & 0 & $<0,00$ \\
\hline Hiçbır şey yapmamak & Hayır & 1 & 4 & 119 & 74 & 32 & 230 & 100 & 1 \\
\hline
\end{tabular}

OYD: Okuryazar değil OY: Okuryazar İÖ: İlköğretim L: Lise YÖ: Yükseköğretim T: Toplam

\section{Tartışma}

Çalışmamıza katılan annelerin ortalama çocuk sayıları 2,1 $\pm 1,07$ olup, ailelerin yüksek oranda çekirdek aile şeklinde yaşadıkları (\%74,3), ateş düşürmek için en sı öneriyi doktorlardan aldıkları $(\% 48,7)$ ve çocukların 168 tanesinin (\%73) sürekli bir doktor tarafından takipte olduğu öğrenildi. $\mathrm{Bu}$ çalışmada annelerin ateş hakkındaki genel bilgi düzeylerinin yetersiz olduğu, endişelerinin fazla olduğu ve ateşi düşürmek adına zaman zaman yanlış tutum ve davranışlarının olduğu görüldü. Literatüre göz attığımızda ateş hakkındaki bilgi ve tutumların sosyoekonomik durum, eğitim seviyesi, kültürel yap1 ve ebeveynlerin yaşı ile değişkenlik gösterdiği ortaya koyulmuştur [4-8].

Yıldırım ve arkadaşlarının 2014'te yaptıkları araştırmada anne yaşı arttıkça ateş hakkındaki bilgi düzeylerinde azalma olduğu şeklinde sonuçlar elde edilmiştir [4]. Çaka ve arkadaşlarının 2015'te yaptığı çalışmada anne yaşı arttıkça ateşli çocuğa yaklaşımda doğru tutum ve bilgi seviyelerinin azaldığ sosyokültürel düzey yükseldikçe de bilgi seviyesinin arttığı gösterilmiştir[5]. Bizim çalışmamızda da eğitim düzeyi arttıkça ateş bilinç düzeyinin yükseldiği izlendi. Çalışmamızda alkol ve sirkeli su pansumanı gibi yanlış periferik soğutma yöntemlerinin kullanım sıklığının az olduğu saptanmıştır (\%0,971, \%0,093). Çöl Araz N. ve arkadaşlarının 2013’te yaptıkları araştırmada sirkeli su kullanım oranının \%40,5, alkollü su kullanım oranının ise \%8,25 olduğu görülmüştür [9]. Crocetti ve arkadaşlarının 2001'de yapmış olduğu çalışmada ateş düşürmek adına alkol kullanım oranı \%18 olarak bulunmuştur [10]. Bu bilgiler 1şı̆̆ında, annelerin yıllar geçtikçe ateşe yaklaşım konusunda daha çok bilinçlendiklerini söyleyebiliriz.

Schmitt 1980 yılında yapmış olduğu çalışmada ateş durumunda ailelerin endişelerini "fever phobia (ateş fobisi)" şeklinde tanımlamıştır [11]. Schmitt'in çalışmasından 20 yıl sonra Crocetti ve arkadaşlarının yaptıkları çalışmada da, 30 yıl sonra Nerkiz ve arkadaşlarının yaptıkları çalışmada da ebeveynlerin ateş fobisinin devam ettiği belirtilmiştir [10,12]. Biz de annelerin ateş durumunda hissettikleri endişe düzeylerini sorguladığımızda; en düşük puan olan 0 (sıfır) \%2,2 oranında, en yüksek puan olan 10 (on) \%26,9 oranında, 6 ve üzeri puanlar toplamda \%63,9 oranında işaretlendi. Ateşin ne olduğu, ateşe sebep olan ve ateşin sebep olabileceği durumlar konusunda annelerin eksik ve yanlış bilgilerinin, ateşin halen bu denli endişeye sebep olmasında önemli etkenler olduğu düşünülmüştür. Çalışmamıza katılan annelerin \%97,8'inin ateş ölçer kullandığını ve ölçümlerin \%79,1 oranında koltuk altından yapıldığını göz önünde bulundurarak; annelerin $\% 57,8^{\prime}$ inin normal vücut sıcaklığını $35,5-36,4^{\circ} \mathrm{C}$ olarak işaretlemesi, yüksek ateşin $38^{\circ} \mathrm{C}$ ve üstü olduğu cevabının sadece $\% 53,0$ oranında verilmesi ve $\% 74,8$ 'inin ateşi bir hastalık olarak görmesi ateş karşısındaki yüksek endişe düzeyini anlamamıza yardım etmektedir.

Annelere yüksek ateşin zararları sorulduğunda en sık verilen cevap $(\% 93,4)$ ateşli havaleydi. Çocukların sadece 13 tanesinde $(\% 5,7)$ febril konvulsiyon hikayesi mevcuttu. Ateşin bir hastalık olarak görülmesi ve febril konvulsiyona neden olacağı anksiyetesi ailelerin ateşe odaklanmalarına ve ateşi düşürmek adına zaman zaman hatalı davranışlarda bulunmalarına neden olmaktadır [10,11,13-15]. Çocukların 168 tanesinin (\%73) sürekli bir doktor tarafindan takipte olduğu öğrenildi (112 tanesi $(\% 66,7)$ çocuk doktoru, 56 tanesi $(\% 33,3)$ aile hekimi). Annelerin ateş düşürmek için doktorlardan öneri alma oranı çalışmamızda \%48,7 olarak bulunurken, bu oran Crocetti ve arkadaşlarının yaptığı çalışmada benzer şekilde \%46 olarak bulunmuştur [10]. 
Bu konuda özellikle aile hekimlerine ve çocuk sağlığı ve hastalıkları hekimlerine önemli görevler düşmektedir. Ailelerin ateş konusunda hekimler tarafından detaylı bilgilendirilmeleri bu konudaki gereksiz uygulamaların önüne geçeceğini düşünmekteyiz.

Ateşi düşürmek için en çok kullanılan antipiretikler parastemol ve ibuprofendir. Parastemol her 4 saatte bir $10-15 \mathrm{mg} / \mathrm{kg}$ dozunda kullanılırken, ibuprofen 8 saatte bir 5-10 mg/kg dozunda kullanılabilir [2]. Ayrıca ibuprofen 6 ay üstü çocuklarda tercih edilmelidir [2]. Çalışmamızda verilen cevaplara göre en çok tercih edilen ateş düşürücü $(\% 76,1)$ parasetamol idi ve genellikle reçeteli temin ediliyordu $(\% 86,5)$. Anneler ateş düşürücü dozunu en sık doktor önerisine göre ayarlarken $(\% 61,7)$, genelde 4 saat ara ile $(\% 60,4)$ ve $38^{\circ} \mathrm{C}$ ve üstünde $(\% 67,8)$ ilaç kullandıkları öğrenildi. Her ne kadar doz ayarlarken yüksek oranda doktor önerisine başvurulsa da, aileler eski bilgileri ile düşük doz ilaç kullanabilirler.

Çalışmamızda ateşi düşürmek için antibiyotik kullanma oranı \%0,4 olarak bulunmuştur. Bayram ve arkadaşlarının 2016'da İzmir'de yaptıkları çalışmada da bizim çalışmamızla benzer sonuçlar elde edilmiştir; ebeveynlerin kendi kendilerine antibiyotik başlama oranı \%0, internetten araştırarak antibiyotik başlama oranı \%4,7 olarak bulunmuştur [16]. Al-Shawi ve arkadaşlarının 2018'de Suudi Arabistan'da yaptıkları çalışmada kulak ve boğaz ağrısı durumunda ailelerin \%63,5 oranında antibiyotik kullandıkları gösterilmiştir [17]. Ülkemizde yapılan çalışmalarda antibiyotik yanlış kullanım oranları düşük gibi görünse de günlük pratikte antibiyotik yanlış kullanımı, özellikle solunum yolları enfeksiyonlarında, sıkça karşılaştığımız bir durumdur.

Çalışmamızın kısıtlılığı olarak; anksiyete düzeyi yüksek olan bazı annelerin çalışmaya katılmak istememesi gösterilebilir. Çalışmamızın sonuçları sadece katılımcıların yaptığı anketler çerçevesinde elde edilmiştir. Bilgilerinin yetersiz olduğunu düşünerek çekindiği için çalışmaya katılmak istemeyen anneler de olabilir. Belirlediğimiz süre içerisinde çalışmamıza katılan anne sayısının 230 olması da araştırmamızın bir diğer kısıtlılı̆̆ıdır.

\section{Sonuç}

Ateş durumunda evde yapılması gereken müdahalelerin yapılması ve gereği halinde hastane başvurularının olması, hem sağlık sektöründe iş gücünün doğru kullanılması hem de sağlık harcamalarının azalması açısından olumlu yönde etki gösterecektir. İlaç kullanımıyla ilgili olarak; çocuk büyüdükçe doz değişimi yapılması gerektiği ailelere hatırlatılmalı ve bilgileri güncellenerek doğru biçimde ilaç kullanmaları sağlanmalıdır. Çocuklu ailelerin panikledikleri ve başa çıkmakta zorlandıkları bir durum olan ateş, ailelerin bu konudaki bilgi düzeyleri arttıkça daha kolay yönetilen bir süreç olacaktır. $\mathrm{Bu}$ konuda bilgilendirici sağlık derslerinin okul müfredatlarına eklenmesi, halk eğitim toplantıları yapılması, televizyon ve sosyal medya gibi geniş kitlelere kolayca ulaşım sağlanabilen mecralarda bilgilendirici yayınlar yapılması ve hekimlerin bu konuda öğretici ve hatırlatıcı görev üstlenmeleri ile ailelerin ateş durumunda doğru tutum ve davranışlar edineceklerini düşünmekteyiz.

Çıkar Çatışması / Conflict of interest: Yok / none.

Finansal Destek / Funding: Yok / none.

\section{Kaynaklar}

1. Y1lmaz AT. Ateş. In:Enfeksiyon Hastalıkları, Yurdakök M (editor). Yurdakök Pediatri, First Ed., Ankara: Güneş Tıp Kitapevleri; 2017: 24352441.

2. Nield LS, Kamat D. Fever. In: İnfectious Diseases, Kliegman RM (editör). Nelson Textbook of Pediatrics, 20th Ed.,Philadelphia: Elsevier; 2016: 1277-1279.

3. Kılıç R, Kendir ÖT, Gökay SS, ve ark. Çocuklarda ateş ile ilgili ebeveynlerin tutum ve davranışları. J Pediatr Emerg Intensive Care Med 2016;3:76-85. doi: https://doi.org/10.4274/cayd.59144.

4. Yıldırım A, Bozaykut A, Dalkan C, ve ark. 16 Ay - 6 yaş arası yüksek ateşli çocukların annelerinin ateş bilinç seviyesinin değerlendirilmesi. Turkish J Pediatr Dis 2014;4:201-207. doi: https://doi.org/10.12956/tjpd.2014.82.

5. Çaka SY, Çınar N, Altınkaynak S. Ateşli çocuğa yaklaşım. J hum rhythm 2015;1(4):133-138.

6. Halıcıŏlu O, Koç F, Aşı AS, ve ark. Ateşli çocuklarda; annelerin evde ateşe yaklaşımı, bilgileri ve sosyodemografik özellikler ile ilişkisi. İzmir Dr. Behçet Uz Çocuk Hast. Dergisi 2011;1(1):13-19. doi: https://doi.org/10.5222/buchd.2011.013.

7. Williams A, O'Rourke P, Keogh S. Making choices: Why parents present to the emergency department non-urgent care. ArcDis Child 2009;94:817-820. doi: https://doi.org/10.1136/adc.2008.149823.

8. Finkelstein JA, Christiansen CL, Platt R. Fever in pediatric primary care: occurrence, management, and out comes. Pediatrics 2000;105:260-266. doi: https://doi.org/10.1136/adc.2008.149823.

9. Çöl Araz N. Ailelerin ateşli çocuğa yaklaşımı: bilgi, tutum ve uygulamaları. Turkish J Pediatr Dis 2013;1:27-32. doi: https://doi.org/10.12956/tipd.2013.1.05.

10. Crocetti M, Moghbeli N, Serwint J. Fever phobia are visited: Have parental misconceptions about fever changed in 20 years? Pediatrics 2001;107:1241-1246. doi: https://doi.org/10.1542/peds.107.6.1241.

11. Schmitt BD. Fever phobia: Misconceptions of parents about fevers. Am J Dis Child 1980;134:176-181.

12. Nerkiz P, Doğaner YÇ, Aydoğan Ü, ve ark. Ailelerin ateşli çocuğa yaklaşımı ve ateş bilinç durumu. Euras J Fam Med 2012;1(1):11-16.

13. Tursun S, Alpcan A. Ailelerin korkusu, ateş. Ortadoğu Tıp Dergisi 2016;8(3):157-159.

14. Özkan H, Öztürk S. Doğu Anadolu bölgesinde bir kent merkezinde iki aile sağlığı merkezine başvuran annelerin çocukları ateşlendiğinde yaptığı uygulamalar. İzmir Dr. Behçet Uz Çocuk Hast. Dergisi 2013; 3(2):121-126. doi:https://doi.org/10.5222/buchd.2013.121.

15. Eliaçık K, Kanık A, Oyman G, ve ark. Ebeveynlerin ateş hakkındaki bilgi, inanış ve yanlış uygulamaları. ADÜ Tıp Fakültesi Dergisi 2012;13(1):57.

16. Bayram N, Günay İ, Apa $\mathrm{H}$ ve ark. Çocuklarda antibiyotik kullanımı ile ilgili ailelerin tutumlarını etkileyen faktörlerin değerlendirilmesi. J Pediatr Inf 2013;7:57-60. doi:https://doi.org/10.5152/ced.2013.16.

17. Al-Shawi MM, Darwish MA, Abdel Wahab MM ve ark. Misconceptions of parents about antibiotic use in upper respiratory tract infections: a survey in primary schools of the eastern province, KSA. J Family Community Med 2018;25(1):5-12. doi: https://doi.org/10.4103/jfcm.JFCM_46_17. 